\title{
Pseudoalteromonas bacteriolytica sp. nov., a marine bacterium that is the causative agent of red spot disease of Laminaria japonica
}

\author{
Tomoo Sawabe, ${ }^{1}$ Hideyuki Makino, ${ }^{1}$ Masahiro Tatsumi, ${ }^{1}$ \\ Kazuaki Nakano, ${ }^{1}$ Kenichi Tajima, ${ }^{1}$ Mohammed Mahbub Iqbal, ${ }^{1}$ \\ Isao Yumoto, ${ }^{2}$ Yoshio Ezura' and Richard Christen ${ }^{3}$
}

Author for correspondence: Tomoo Sawabe. Tel: +8113840 5569. Fax: +81138405569. e-mail: sawabe@pop.fish.hokudai.ac.jp

\footnotetext{
1 Laboratory of

Microbiology, Faculty of Fisheries, Hokkaido University, 3-1-1 Minatocho, Hakodate 041, Japan

2 Bioscience and Chemistry Division, Hokkaido National Industrial Research Institute, 2-17-2-1 Tsukisamu-Higashi, Toyohira-ku, Sapporo 062 . Japan

${ }^{3}$ Centre National de la Recherche Scientifique et Université, Pierre et Marie Curie, Station Zoologique, Villefranche-sur-Mer 06230, France
}

\begin{abstract}
An aerobic, polarly flagellated marine bacterium that produces a prodigiosinlike pigment was isolated from the red-spotted culture beds of Laminaria japonica. Five isolates had unique bacteriolytic activity for both Gram-positive and-negative bacteria, which had never been observed among Alteromonas or related species. The isolates were identified as the causative agent of red spot disease of $L$. japonica seeds. The phenotypic features of the isolates were similar to these of Pseudoalteromonas rubra ATCC 29570', but they could be differentiated using 10 traits (growth at $37^{\circ} \mathrm{C}$, requirement for organic growth factors, bacteriolytic activity, utilization of sucrose, $\mathrm{N}$-acetylglucosamine, fumarate, succinate, D-galactose, L-proline and acetate). The $G+C$ content of DNAs from the isolates was $44-46$ mol\%. The isolates constitute a new species, distinct from the other A/teromonas and Pseudoalteromonas species, as shown by DNA-DNA hybridization experiments and phylogenetic clustering of 165 rRNA gene sequences, for which the name Pseudoalteromonas bacteriolytica sp. nov. (type strain = IAM 14595') is proposed. A set of phenotypic features which differentiate this new species from closely related Pseudoalteromonas and Alteromonas species is provided.
\end{abstract}

Keywords: Pseudoalteromonas bacteriolytica sp. nov., bacteriolytic activity, red spot disease, Laminaria

\section{INTRODUCTION}

In 1984, a bacterium producing a prodigiosin-like red pigment was isolated from red-spotted culture beds of Laminaria japonica (7). The bacterium was an aerobic, polarly flagellated marine bacterium, and it was suggested that the bacteria could be assigned to the genus Alteromonas (7). In addition, the bacterium showed a broad spectrum of bacteriolytic activity. Presently, at least six bacteriolytic substances, including bacteriolytic enzymes, have been detected in culture supernatants and cell-bound fractions $(19,20)$. An ecological function of this bacteriolytic activity has been proposed, which would allow maintenance of the bacterial population in oligotrophic aquatic environments (21).

The DDBJ/GenBank/EMBL accession number for the sequence of Pseudoalteromonas bacteriolytica (IAM 14595') is D89929.
Originally consisting of four species, the genus Alteromonas included Gram-negative, aerobic, non-pigmented, polarly flagellated species of marine bacteria, which differed from the genus Pseudomonas by a lower $\mathrm{G}+\mathrm{C}$ content $(1,2)$. Recently, following phylogenetic analyses of $16 \mathrm{~S}$ rDNA sequences, the genus was divided into two new genera, the emended genus Alteromonas and the new genus Pseudoalteromonas. Now, at least 14 species, most of which were previously Alteromonas species, are included in the genus Pseudoalteromonas, and the emended genus Alteromonas is restricted to a single species, Alteromonas macleodii, with two subspecies $(8,15)$. Bacteriolytic Pseudoalteromonas or Alteromonas strains have never been described previously. The precise taxonomic position of the aforementioned bacteriolytic bacterium therefore remains uncertain. In this study, DNA-DNA hybridizations, phenotypic characterization and phylogenetic analyses were performed to clarify the taxonomic assignment of the causative agent of red 
spot disease of L. japonica seeds. All of the data suggest that this bacterium is a new species of Pseudoalteromonas, for which we propose the name Pseudoalteromonas bacteriolytica.

\section{METHODS}

Bacterial strains. Strains used in this study are listed in Table 1. Five strains (No. 8R, E-1, E-2 and A3), including the type strain IAM $14595^{\mathrm{T}}$ had been isolated from red-spotted culture beds of $L$. japonica (7). These isolates of Pseudoalteromonas bacteriolytica were maintained on CSY-3 agar medium containing casitone (Difco) $1.0 \mathrm{~g}$, Difco bactosoytone $1.0 \mathrm{~g}$, Difco yeast extract $1.0 \mathrm{~g}$, ferric ammonium citrate $0.1 \mathrm{~g}$, and $1000 \mathrm{ml}$ natural seawater, $\mathrm{pH} 7.5(19)$. The stock cultures were maintained in CSY-3 broth containing $20 \%$ glycerol (v/v). All reference strains were maintained on ZoBell 2216E agar medium (13).

Morphological, biochemical and physiological characterization. Conventional phenotypic characteristics of $P$. bacteriolytica, P. rubra, P. haloplanktis subsp. haloplanktis and $A$. macleodii were determined by the methods described by Baumann et al. (2), Hidaka \& Sakai (9), Holt et al. (10), Leifson (11), Oppenheimer \& ZoBell (13), Ostle \& Holt (14) and West et al. (22). Bacteriolytic activity was determined by the formation of a clear zone on the plate using the CSY-3 agar medium including freeze-dried cells of Micrococcus luteus (Seikagaku Kogyo). This medium was prepared according to the methods of Yumoto et al. (20). Briefly, 0.5 $\mathrm{ml}$ viable cell suspension of $M$. luteus (approx. $10^{10} \mathrm{ml}^{-1}$ in natural seawater) was added to $2.5 \mathrm{ml}$ melted agar $(0.8 \%$ in natural seawater) at $45^{\circ} \mathrm{C}$. It was then poured onto a base of CSY-3 agar medium. After $5 \mathrm{~d}$ incubation, the formation of a clear zone around the spotted culture was determined.

Determination of $\mathbf{G}+\mathbf{C}$ content and DNA-DNA hybridization. DNA from bacterial strains was prepared by the procedures of Marmur (12), with minor modification. $G+C$ contents of DNA were determined according to the melting temperature $\left(T_{\mathrm{m}}\right)$ of the DNA. DNA-DNA hybridization experiments were performed in microdilution wells using a fluorometric direct binding method (5) under conditions previously described by Sawabe et al. (17). DNAs from Pseudoalteromonas bacteriolytica IAM $14595^{\mathrm{T}}$ and Pseudoalteromonas rubra ATCC $29570^{\mathrm{T}}$ were labelled with photobiotin (Vector Laboratories). The hybridization of the biotinylated DNA to immobilized DNAs was performed under optimal conditions following pre-hybridization, and then biotinylated DNA that hybridized to immobilized DNA was detected by a fluorimetric method after binding streptavidin- $\beta$-galactosidase to labelled DNA. 4-Methylumbelliferyl- $\beta$-D-galactopyranoside $\left(6 \times 10^{-4} \mathrm{M}\right.$; Wako $)$ was added to each well as fluorogenic substrate for $\beta$-galactosidase prior to incubation at $30^{\circ} \mathrm{C}$. Fluorescence intensity of the well was then measured using the MicroFluoro reader (MTP-22; Corona Electric) at wavelengths of $360 \mathrm{~nm}$ for excitation and $450 \mathrm{~nm}$ for emission. DNA-DNA homology was calculated according to the method of Ezaki et al. (6).

DNA amplification and sequencing. Bacterial DNAs for PCR were prepared according to the methods of Enright $e t$ al. (4). One hundred nanograms of DNA templates were

Table 1. DNA relatedness among Pseudoalteromonas, Alteromonas and Marinomonas strains

\begin{tabular}{|c|c|c|c|c|}
\hline \multirow[t]{2}{*}{ Strain } & & \multirow[t]{2}{*}{$\begin{array}{c}\mathbf{G}+\mathbf{C} \text { content } \\
(\mathrm{mol} \%)\end{array}$} & \multicolumn{2}{|c|}{$\begin{array}{l}\text { Reassociation (\%) with biotinylated } \\
\text { DNA from: }\end{array}$} \\
\hline & & & $\begin{array}{l}\text { P. bacteriolytica } \\
\text { IAM 14595 }\end{array}$ & $\begin{array}{l}\text { P. rubra ATCC } \\
29570^{\mathrm{T}}\end{array}$ \\
\hline P. bacteriolytica & IAM $14595^{\mathrm{T}}$ & 46 & $100 \cdot 0$ & $3 \cdot 4$ \\
\hline P. bacteriolytica & No. $8 \mathrm{R}$ & 44 & $92 \cdot 4$ & NT \\
\hline P. bacteriolytica & E-1 & 45 & $99 \cdot 3$ & NT \\
\hline P. bacteriolytica & $\mathrm{E}-2$ & 44 & $98 \cdot 3$ & NT \\
\hline P. bacteriolytica & A-3 & 46 & $93 \cdot 5$ & NT \\
\hline P. rubra & ATCC $29570^{\mathrm{T}}$ & 46 & $5 \cdot 6$ & $100 \cdot 0$ \\
\hline A. macleodii & IAM $12920^{\mathrm{T}}$ & $46 \cdot 2^{*}$ & $2 \cdot 6$ & $3 \cdot 9$ \\
\hline P. espejiana & IAM $12640^{\mathrm{T}}$ & $41 \cdot 4^{*}$ & $3 \cdot 3$ & $4 \cdot 1$ \\
\hline$P$. atlantica & NCIMB $301^{\mathrm{T}}$ & $41 \cdot 2^{*}$ & $4 \cdot 5$ & $3 \cdot 2$ \\
\hline P. carrageenovora & NCIMB $302^{\mathrm{T}}$ & $39 \cdot 5^{*}$ & 3.9 & $2 \cdot 2$ \\
\hline P. marinovulgaris & ATCC 14394 & NT & $3 \cdot 1$ & $3 \cdot 4$ \\
\hline$P$. nigrifaciens & IAM $13010^{\mathrm{T}}$ & $40 \cdot 6^{*}$ & $4 \cdot 1$ & $4 \cdot 5$ \\
\hline P. haloplanktis & IAM $12915^{\mathrm{T}}$ & $41 \cdot 6^{*}$ & $3 \cdot 7$ & $5 \cdot 8$ \\
\hline P. haloplanktis & ATCC 19648 & $40 \cdot 5^{*}$ & $4 \cdot 1$ & $6 \cdot 0$ \\
\hline P. undina & IAM $12922^{\mathrm{T}}$ & $40 \cdot 1^{*}$ & 3.9 & $4 \cdot 3$ \\
\hline P. piscicida & NCIMB $645^{\mathrm{T}}$ & $43-46^{*}$ & $3 \cdot 7$ & $7 \cdot 5$ \\
\hline M. communis & IAM $12914^{\mathrm{T}}$ & $47 \cdot 0^{*}$ & $3 \cdot 3$ & $2 \cdot 2$ \\
\hline M. vaga & IAM $12923^{\mathrm{T}}$ & $48 \cdot 4^{*}$ & $3 \cdot 1$ & $2 \cdot 8$ \\
\hline
\end{tabular}

NT, Not tested.

* Data from reference 2. 


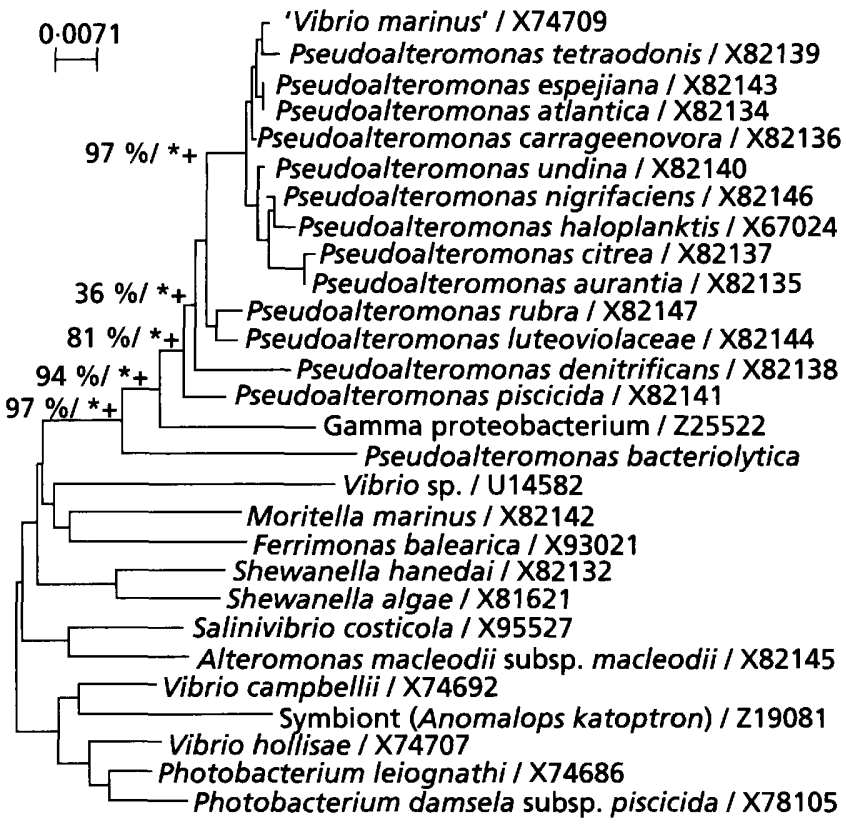

Fig. 1. Unrooted phylogenetic tree showing phylogenetic relationships for a selection of bacteria belonging to the gamma 3 subclass, Pseudoalteromonas and Alteromonas. The figure combines the results of three analyses, neighbourjoining, maximum-parsimony and maximum-likelihood. The topology shown was obtained by neighbour-joining, and the percentages are the result of a bootstrap analysis using 100 replications. Branches also obtained in the maximum-likelihood analysis are indicated by * $(P<0.01)$. Monophyletic units also obtained in the most parsimonious tree are indicated by + . Scale bar, 0.0071 accumulated changes per nucleotide.

used in a PCR to amplify the small-subunit rRNA genes as previously described by Sawabe et al. (17). PCR conditions were as follows; the initial denaturation step at $94^{\circ} \mathrm{C}$ for $180 \mathrm{~s}$, an annealing step at $55^{\circ} \mathrm{C}$ for $60 \mathrm{~s}$ and an extension step at $72^{\circ} \mathrm{C}$ for $90 \mathrm{~s}$. The thermal profile then consisted of 30 cycles. The amplification primers used in this study gave a $1.5 \mathrm{kbp}$ PCR product and corresponded to positions 25-1521 in the Escherichia coli sequence. The PCR products were purified by PEG 6000 and directly sequenced by using a Taq FS dye terminator sequencing kit (ABI) and the protocol recommended by the manufacturer. DNA sequencing was performed with an Applied Biosystems model 373A automated sequencer (17). Nine sequencing primers were used for sequencing (17).

Phylogenetic analysis. The sequences were aligned and studied using a set of programs developed by $R$. Christen. In all phylogenetic analyses, we used the sequences determined in this study and small-subunit rDNA sequences obtained from the EMBL database. For Fig. 1, the following sequences were used: Pseudoalteromonas denitirificans ATCC $43337^{\mathrm{T}}$, X82138; Pseudoalteromonas citrea NCIMB $1889^{\mathrm{T}}$, X82137; Pseudoalteromonas aurantia ATCC $33046^{\mathrm{T}}$, X82135; Pseudoalteromonas atlantica IAM 12927 $7^{\mathrm{T}}, \mathrm{X} 82134$; Pseudoalteromonas espejiana NCIMB 2127 ${ }^{\mathrm{T}}$ X82143; Pseudoalteromonas carrageenovora ATCC 12662 ${ }^{\mathrm{T}}$, X82136; Pseudoalteromonas undina NCIMB 2128 ${ }^{\mathrm{T}}$, X82140; Pseudoalteromonas haloplanktis ATCC 14393, X67024; Pseudoalteromonas nigrifaciens NCIMB 8614 ${ }^{\mathrm{T}}$, X82146; Pseudo- alteromonas tetraodonis IAM 14160 ${ }^{\mathrm{T}}$, X82139; Pseudoalteromonas piscicida C201 CERBOM, X82141; Pseudoalteromonas rubra ATCC $29570^{\mathrm{T}}$, X82147; Pseudoalteromonas luteoviolacea NCIMB 1893 ${ }^{\mathrm{T}}$, X82144; Alteromonas macleodii subsp. macleodii IAM 12920", X82145; 'Vibrio marinus' ATCC $15831^{\mathrm{T}}$, X74709; Vibrio sp., U145842; Moritella marinas NCIMB 1144 ${ }^{\mathrm{T}}$, X82142; Ferrimonas balearica, X93021; Shewanella hanedai CIP $103207^{\mathrm{T}}$, X82132; Shewanella algae, X81621; Salinivibrio costicola NCIMB 701 ${ }^{\mathrm{T}}$, X95527; Vibrio campbellii ATCC $25920^{\mathrm{T}}$, X74692; symbiont Anomolops katoptron, Z19081; Vibrio hollisae ATCC 33564' ${ }^{\mathrm{T}}$ X74707; Photobacterium leiognathi ATCC $25521^{\mathrm{T}}$, X74686; and Photobacterium damsela subsp. piscicida NCIMB 2058, X78105.

Domains used to construct the dendrogram shown in Fig. 1 were regions of the small-subunit rDNA sequences available for all sequences and excluding positions likely to show homoplasy: positions $251-434,493-590,653-835,855-997$, 1045-1114, 1156-1354 (E. coli small-subunit rDNA sequence J01695 numbering). Phylogenetic analyses were performed by using three different methods, neighbourjoining (16), maximum-likelihood (options QFYG, fastDNAml program of G. J. Olsen, University of Illinois, Urbana, USA) and maximum-parsimony [PAUP 3.0s for the Macintosh, heuristic search (18)]. The robustness of each topology was checked by using the neighbour-joining method and 100 bootstrap replications. Trees were drawn by using the njplot program for the Macintosh (M. Gouy, CNRS URA 243, Université Claude Bernard, Lyon, France).

\section{RESULTS AND DISCUSSION}

The five strains isolated from red-spotted culture beds appeared as polarly flagellated, Gram-negative, nonfermentative rods (Table 2 ). The bacterium required salt for its growth, did not accumulate poly- $\beta$-hydroxybutyrate and did not reduce nitrate (Table 2). No peritrichous flagella were observed when the bacterium was cultivated on solid media. The $\mathrm{G}+\mathrm{C}$ contents of the strains were $4446 \mathrm{~mol} \%$ (Table 1), suggesting that this bacterium should be assigned either to the genus Alteromonas or to the genus Pseudoalteromonas $(2,10)$.

Specific biochemical and physiological features of strain IAM $14595^{\mathrm{T}}$, No. $8 \mathrm{R}, \mathrm{E}-1, \mathrm{E}-2$ and A-3 are shown in Table 2. Morphological, biochemical and physiological characteristics of these strains including IAM $14595^{\mathrm{T}}$ were most closely related to that of Pseudoalteromonas rubra ATCC $29570^{\mathrm{T}}$ among $\mathrm{Al}$ teromonas, Pseudoalteromonas, Marinomonas and related species. Phenotypic characteristics of Pseudoalteromonas haloplanktis subsp. haloplanktis IAM $12915^{\mathrm{T}}$, type species of Pseudoalteromonas (8), or Alteromonas macleodii IAM $12920^{\mathrm{T}}$, type species of Alteromonas (8), are also quite different from our strains (Table 2). Ten traits were different between these species: bacteriolytic activity, growth at $37^{\circ} \mathrm{C}$, requirement for organic growth factors, utilization of sucrose, $N$-acetylglucosamine, fumarate, succinate, Dgalactose, L-proline and acetate (Table 2). Pseudoalteromonas denitrificans also produced prodigiosinlike pigment (3), but a significant number of bio- 
Table 2. Phenotypic characteristics for distinguishing Pseudoalteromonas bacteriolytica from $P$. rubra, $P$. haloplanktis subsp. haloplanktis and Alteromonas macleodii

O, Oxidative; pol, polar flagellum; WP, weakly positive; d, different reactions; ( ), result of $P$. bacteriolytica IAM $14595^{\mathrm{T}}$.

\begin{tabular}{|c|c|c|c|c|}
\hline Characteristic & $\begin{array}{c}\text { P. bacteriolytica } \\
\text { IAM 14595', No. } \\
\text { 8R, E-1, E-2 and } \\
\text { A-3 }\end{array}$ & $\begin{array}{c}\text { P. rubra ATCC } \\
2_{29570^{\mathrm{T}}}\end{array}$ & $\begin{array}{c}\text { P. haloplanktis } \\
\text { subsp. } \\
\text { haloplanktis IAM } \\
1^{12915} \\
\end{array}$ & $\begin{array}{l}\text { A. macleodii } \\
\text { IAM } 12920^{1}\end{array}$ \\
\hline Pigmentation & + & + & - & - \\
\hline Water-insoluble & Red & Red & & \\
\hline Salt requirement & + & + & + & + \\
\hline OF test & $\mathrm{O}$ & $\mathrm{O}$ & $\mathrm{O}$ & $\mathrm{O}$ \\
\hline Flagellar arrangement & pol & pol & pol & pol \\
\hline \multicolumn{5}{|l|}{ Growth at: } \\
\hline $4{ }^{\circ} \mathrm{C}$ & - & - & + & - \\
\hline $37^{\circ} \mathrm{C}$ & - & + & - & + \\
\hline $40^{\circ} \mathrm{C}$ & - & - & - & + \\
\hline Oxidase & + & + & + & + \\
\hline Catalase & WP & + & + & + \\
\hline \multicolumn{5}{|l|}{ Production of: } \\
\hline Amylase & + & + & - & + \\
\hline Alginase & - & - & - & + \\
\hline Agarase & - & - & - & - \\
\hline Lipase & + & + & + & + \\
\hline Chitinase & - & - & - & - \\
\hline Gelatinase & + & + & + & + \\
\hline Caseinase & + & + & + & + \\
\hline$\kappa$-Carrageenase & - & - & - & - \\
\hline Bacteriolytic activity & + & - & - & - \\
\hline $\mathrm{NO}_{3}^{-}$reduced to $\mathrm{NO}_{3}^{-}$ & - & - & - & - \\
\hline Requirement for organic growth factors & + & - & - & - \\
\hline \multicolumn{5}{|l|}{ Utilization of: } \\
\hline D-Mannose & + & + & - & - \\
\hline D-Fructose & + & + & + & + \\
\hline Sucrose & + & - & - & + \\
\hline Maltose & $\mathrm{d}(-)$ & + & + & + \\
\hline D-Gluconate & - & - & + & + \\
\hline D-Glucosamine & + & + & - & - \\
\hline $\mathrm{N}$-Acetylglucosamine & - & + & - & + \\
\hline D-Mannitol & $\mathrm{d}(-)$ & - & + & + \\
\hline Fumarate & + & - & + & - \\
\hline Succinate & + & - & + & + \\
\hline D-Sorbitol/citrate & - & - & - & - \\
\hline $\begin{array}{l}\text { meso-Erythritol/glycerol/ } \\
\text { m-hydroxybenzoate/DL-malate/ } \\
\alpha \text {-ketoglutarate }\end{array}$ & - & - & - & - \\
\hline D-Galactose & + & - & - & + \\
\hline Cellobiose & $d(-)$ & - & + & + \\
\hline Melibiose & - & - & - & + \\
\hline Lactose & - & - & - & + \\
\hline Xylose & - & - & - & + \\
\hline Trehalose & $\mathrm{d}(+)$ & + & + & - \\
\hline$\gamma$-Aminobutyrate & - & - & - & + \\
\hline L-Proline & - & + & + & + \\
\hline Acetate & + & - & + & + \\
\hline Pyruvate & $\mathrm{d}(+)$ & + & + & + \\
\hline
\end{tabular}


Table 2 (cont.)

\begin{tabular}{|c|c|c|c|c|}
\hline Characteristic & $\begin{array}{c}\text { P. bacteriolytica } \\
\text { IAM 14595', No. } \\
\text { 8R, E-1, E-2 and } \\
\text { A-3 }\end{array}$ & $\begin{array}{c}P . \text { rubra ATCC } \\
29570^{\mathrm{T}}\end{array}$ & $\begin{array}{c}\text { P. haloplanktis } \\
\text { subsp. } \\
\text { haloplanktis IAM } \\
1_{2915}\end{array}$ & $\begin{array}{l}\text { A. macleodii } \\
{\text { IAM } 12920^{\mathrm{T}}}^{\text {A }}\end{array}$ \\
\hline L-Tyrosine & $\mathrm{d}(-)$ & - & - & + \\
\hline Aconitate & - & - & - & - \\
\hline L-Glutamate & $\mathrm{d}(+)$ & - & + & + \\
\hline D-Glucose/propinonate & + & + & + & + \\
\hline D-Glucronate/putrescine $/ \delta$-aminovarate & - & - & - & - \\
\hline Growth on $\mathrm{KCN}$ & - & - & - & - \\
\hline PHB accumulation & - & - & - & - \\
\hline
\end{tabular}

chemical characteristics including $\mathrm{G}+\mathrm{C}$ content of the species were different from our strains.

DNA-DNA hybridization results (Table 1) showed that the four other isolates were more than $90 \%$ similar to IAM $14595^{\mathrm{T}}$. DNA-DNA homology values between IAM $14595^{\mathrm{T}}$ and representatives of the genera Pseudoalteromonas, Marinomonas and Alteromonas, used in this study were distinctively low (Table 1). There was no significant homology when Pseudoalteromonas rubra ATCC $29570^{\mathrm{T}}$ was photobiotinylated and hybridization was performed between Pseudoalteromonas rubra ATCC $29570^{\mathrm{T}}$ and IAM $14595^{\mathrm{T}}$ (Table 1).

The 16S rDNA sequence of strain IAM $14595^{\mathrm{T}}$ was aligned by comparison to a database containing about 5000 already aligned eubacterial small-subunit rDNA sequences. The results of broad phylogenetic analyses clearly showed that the sequence which we studied belonged to the gamma subclass of the Proteobacteria (data not shown), and more precisely, to the gamma 3 subclass. More detailed analyses showed that it could be included in the Pseudoalteromonas genus, with which it formed a robust clade (and in agreement with phenotypic data) although it was the deepest branch of the genus Pseudoalteromonas (Fig. 1). Homology levels for nucleotides of $16 \mathrm{~S}$ rDNAs from Pseudoalteromonas bacteriolytica and closely related species were very low, ranging from $87.7 \%$ (against gamma proteobacterium Z25522) to $90 \cdot 3 \%$ (against Pseudoalteromonas carrageenovora and Pseudoalteromonas espejiana). This finding was also revealed by the DNA-DNA homology results, in which IAM $14595^{\mathrm{T}}$ showed a very low level of relatedness with the other species of Pseudoalteromonas (Table 1). It was also separated from Alteromonas macleodii subsp. macleodii (Fig. 1). From the results of the DNA-DNA hybridization (Table 1) and 16S rRNA (Fig. 1) experiments, it was revealed that the strain IAM $14595^{\mathrm{T}}$ and the other four strains, which are the causative agents of red spot disease of $L$. japonica, should be recognized as a new species. The name proposed for this bacterium with a unique bacteriolytic activity and that induces damages in Laminaria seed supply is Pseudoalteromonas bacteriolytica.

\section{Description of Pseudoalteromonas bacteriolytica sp.} nov.

Pseudoalteromonas bacteriolytica (bac.te.rio.ly'ti.ca. Gr. n. baktron rod or staff; Gr. adj. lytica dissolving; M.L. fem. adj. bacteriolytica bacteria-dissolving).

Gram-negative, strictly aerobic, polarly flagellated bacterium isolated from red-spotted culture beds of Laminaria japonica. Cells are rod-shaped, with rounded ends, and are $0.6-0.9 \mu \mathrm{m}$ in diameter and $1.9-2.5 \mu \mathrm{m}$ long when the organism is grown on CSY3 agar medium; the cells occur singly or in pairs. No endospores or capsules are formed. Peritrichous flagellation is not observed when the organism is cultivated on solid media. Colonies on CSY-3 agar medium are red (although non-pigmented colonies frequently occurred), circular, and smooth and convex with entire edges. Mesophilic and neutrophilic chemo-organotroph which grows at temperatures ranging from 15 to $35^{\circ} \mathrm{C}$. No growth occurs at $37^{\circ} \mathrm{C}$. Positive for acid production from glucose, hydrolysis of starch, Tween 80 and casein; weakly positive for catalase; positive for oxidase; assimilates D-mannose, D-fructose, sucrose, D-glucosamine, fumarate, succinate, D-glucose, $D$-galactose, acetate and propionate. Negative for luminescence, production of fluorescein and pyocyanin; hydrolysis of agar, chitin and $\kappa$-carrageenan; nitrate reduction; growth on $\mathrm{KCN}$; accumulation of poly- $\beta$-hydroxybutyrate; assimilation of D-gluconate, $N$-acetylglucosamine, D-sorbitol, citrate, meso-erythritol, glycerol, DL-malate, $\alpha$-ketoglutarate, m-hydroxybenzoate, melibiose, lactose, D-glucronate, xylose, putrescine, $\delta$-aminovarate, $\gamma$-aminobutyrate, L-proline, aconitate (Table 2). The $\mathrm{G}+\mathrm{C}$ content of the DNA is $44-46 \mathrm{~mol} \%$. The type strain is IAM $14595^{\mathrm{T}}$ (Table 1).

\section{REFERENCES}

1. Baumann, L., Baumann, P., Mandel, M. \& Allen, R. D. (1972). Taxonomy of aerobic marine eubacteria. $J$ Bacteriol 110 , $402-429$.

2. Baumann, P., Gauthier, M. J. \& Baumann, L. (1984). Genus Alteromonas Baumann, Baumann, Mandel and Allen 1972, 418. ${ }^{\mathrm{AL}}$ In Bergey's Manual of Systematic Bacteriology, vol. 
1, pp 343-352. Edited by N. R. Krieg \& J. G. Holt. Baltimore: Williams \& Wilkins.

3. Enger, O., Nygaard, H., Solberg, M., Schel, G., Nielsen, J. \& Dundas, I. (1987). Characterization of Alteromonas denitrificans sp. nov. Int J Syst Bacteriol 37, 416-421.

4. Enright, M. C., Carter, P. E., MacLean, I. A. \& McKenzie, H. (1994). Phylogenetic relationships between some members of the genera Neisseria, Acinetobacter, Moraxella, and Kingella based on partial $16 \mathrm{~S}$ ribosomal DNA sequence analysis. Int J Syst Bacteriol 44, 387-391.

5. Ezaki, T., Hashimoto, Y., Takeuchi, N., Yamamoto, H., Liu, S.-L., Miura, H., Matsui, K. \& Yabuuchi, E. (1988). Simple genetic method to identify viridans group Streptococci by colorimetric dot hybridization and fluorometric hybridization in microdilution wells. $J$ Clin Microbiol 26, 1708-1713.

6. Ezaki, T., Hashimoto, Y. \& Yabuuchi, E. (1989). Fluorometric deoxyribonucleic acid-deoxyribonucleic acid hybridization in microdilution wells as an alternative to membrane filter hybridization in which radioisotopes are used to determine genetic relatedness among bacterial strains. Int $J$ Syst Bacteriol 39, 224-229.

7. Ezura, Y., Yamamoto, H. \& Kimura, T. (1988). Isolation of a marine bacterium that produces red-spots on the culture bed of makonbu Laminaria japonica cultivation. Nippon Suisan Gakkaishi 54, 665-672 (in Japanese).

8. Gauthier, G., Gauthier, M. \& Christen, R. (1995). Phylogenetic analysis of the genera Alteromonas, Shewanella, and Moritella using genes coding for small-subunit rRNA sequences and division of the genus Alteromonas into two genera, Alteromonas (emended) and Pseudoalteromonas gen. nov., and proposal of twelve new species combinations. Int J Syst Bacteriol 45, 755-761.

9. Hidaka, T. \& Sakai, M. (1968). Comparative observation of inorganic salt requirement of the marine and terrestrial bacteria. In Proceedings of U.S. and Japan Seminar on Marine Microbiology, pp. 125-149. Edited by H. Kadota \& N. Taga. Bull Misaki Mar Biol Inst Kyoto Univ No. 12.

10. Holt, J. G., Krieg, N. R., Sneath, P. H. A., Staley, J. T. \& Williams, S.T. (editors) (1994). Gram-negative aerobic/ microaerophilic rods and cocci. In Bergey's Manual of Determinative Microbiology, 9th edn, pp. 71-174. Baltimore: Williams \& Wilkins.
11. Leifson, E. (1963). Determination of carbohydrate metabolism of marine bacteria. $J$ Bacteriol 82, 33-36.

12. Marmur, 1. (1961). A procedure for the isolation of deoxyribonucleic acid from microorganisms. J Mol Biol 3, 208-218.

13. Oppenheimer, C. H. \& ZoBell, C. E. (1952). The growth and viability of sixty-three species of marine bacteria as influenced by hydrostatic pressure. J Mar Res 11, 10-18.

14. Ostle, A. G. \& Holt, J. G. (1982). Nile blue A as a fluorescent stain for poly- $\beta$-hydroxybutyrate. Appl Environ Microbiol 44, 238-241.

15. Raguenes, G., Pignet, P., Gauthier, G., Peres, A., Christen, R., Rougeaux, H., Barbier, G. \& Guezennec, J. (1995). Description of a new polymer-secreting bacterium from a deep-sea hydrothermal vent, Alteromonas macleodii subsp. fijensis, and preliminary characterization of the polymer. Appl Environ Microbiol 62, 67-73.

16. Saitou, N. \& Nei, M. (1987). The neighbor-joining method: a new method for reconstructing phylogenetic trees. $\mathrm{Mol}$ Biol Evol 4, 406-425.

17. Sawabe, T., Sugimura, I., Ohtsuka, M., Nakano, K., Tajima, K., Ezura, Y. \& Christen, R. (1998). Vibrio halioticoli sp. nov., a non-motile alginolytic marine bacterium isolated from the gut of abalone Haliotis discus hannai. Int J Syst Bacteriol 48, 573-580.

18. Swofford, D. (1992). PAUP: phylogenetic analysis using parsimony, version $3.0 \mathrm{~s}$. Illinois Natural History Survey, Champaign, IL, USA.

19. Takamoto, S., Yamada, K. \& Ezura, Y. (1994). Production of bacteriolytic enzymes during the growth of a marine bacterium Alteromonas sp. No. 8-R. J Gen Appl Microbiol 40, 499-508.

20. Yumoto, I., Yamaguchi, K., Yamada, K., Ezura, Y. \& Kimura, T. (1989). Relationship between bacterial flora and occurrence of the Alteromonas sp., the causative agent of redspots on the culture bed of makonbu Laminaria japonica, in the coastal area of Funka Bay. Nippon Suisan Gakkaishi 55, 1907-1914.

21. Yumoto, I., Yamada, K., Ezura, Y. \& Kimura, T. (1994). Interaction of Alteromonas sp., a nonobligate bacterial predator, and bacterial prey in artificial seawater. Bull Jpn Soc Microb Ecol 3, 101-108.

22. West, M., Burdash, N. M. \& Freimuth, F. (1977). Simplified silver plating stain for flagella. J Clin Microbiol 6, 414-419. 